\title{
Role of Adiponectin in prostate cancer
}

\author{
Xiaobo Hu ${ }^{1,2}$, Cong Hu ${ }^{2}$, Caiping Zhang ${ }^{2}$, Min Zhang ${ }^{2}$, Shiyin Long ${ }^{2}$, Zhaohui Cao ${ }^{1,2}$ \\ ${ }^{1}$ Hunan Province Cooperative Innovation Center for Molecular Target New Drug Study, University of \\ South China, Hengyang, China; ${ }^{2}$ Department of Biotechnology, School of Pharmacy and Biosciences, \\ University of South China, Hengyang, China
}

\section{ABSTRACT}

Obesity is defined as a chronic and excessive growth of adipose tissue. It has been associated with a high risk for development and progression of obesity-associated malignancies, while adipokines may mediate this association. Adiponectin is an adipose tissue-derived adipokines, with significant anti-diabetic, anti-inflammatory, anti-atherosclerotic and anti-proliferative properties. Plasma adiponectin levels are decreased in obese individuals, and this feature is closely correlated with development of several metabolic, immunological and neoplastic diseases. Recent studies have shown that prostate cancer patients have lower serum adiponectin levels and decreased expression of adiponectin receptors in tumor tissues, which suggests plasma adiponectin level is a risk factor for prostate cancer. Furthermore, exogenous adiponectin has exhibited therapeutic potential in animal models. In this review, we focus on the potential role of adiponectin and the underlying mechanism of adiponectin in the development and progression of prostate cancer. Exploring the signaling pathways linking adiponectin with tumorigenesis might provide a potential target for therapy.

\section{ARTICLE INFO}

\author{
Keywords: \\ Prostatic Neoplasms; Obesity; \\ Stress, Physiological
}

Int Braz J Urol. 2019; 45: 220-8

\author{
Submitted for publication: \\ April 12, 2018 \\ Accepted after revision: \\ September 13, 2018 \\ Published as Ahead of Print: \\ January 03, 2019
}

\section{INTRODUCTION}

Prostate cancer (PC) recently became the second most prevalent cancer afflicting men, and the fifth leading cause of cancer related death throughout the World $(1,2)$. Age, familial history, smoking, sedentary lifestyle and overweight are all factors in the pathogenesis of PC. Of note, obesity is well known as an increased risk for several cancers (including colon, ovary, breast, esophagus and pancreatic), also for PC $(3,4)$. The links between obesity and PC are complicated. Three possible mechanisms are proposed to help explain the association between obesity and the increased risk of PC: the insulin / insulin-like growth fac- tor-1 (IGF-1) axis, sex hormones and adipokines signaling $(5,6)$. Adiponectin (APN), an adipocyte-secreted adipokine, operates in the maintenance of many physiological functions, having potential benefits in the prevention of certain diseases. It mainly regulates inflammation and influences glucose and lipid metabolism through its insulin sensitizing effects $(7,8)$. Recently, APN was proved to be one of the mediators in the development and progression of several types of obesity-associated cancers (9). In this report, we summarized recent findings on the potential role of APN and the underlying mechanism of APN in PC. In addition, the clinical values of APN for PC patients will also be highlighted. 
Adiponectin and its receptors

Adiponectin, also called Acrp30, is a 28$30-\mathrm{kDa}$ adipokine produced mainly by adipose tissue. Full-length APN (fAPN) consists of an N-terminal signal sequence, a short hypervariable region, a collagen-like domain and a C-terminal globular domain $(10,11)$. Pre-secretion, posttranslational processing generates trimers, hexamers, and high molecular weight (HMW)-APN. HMW-APN appears to be the physiologically most relevant and dominant form in plasma (10). Fruebis et al. (11) identified the fourth fraction of APN in the plasma, the globular domain of APN (gAPN), which is generated by the proteolytic cleavage of fAPN.

Normal plasma APN levels range from 5 to $30 \mu \mathrm{g} / \mathrm{mL}$, accounting for up to $0.05 \%$ of total plasma proteins in humans (11). Despite the fact that APN is produced mainly by adipose tissue, its serum concentration is reversely correlated with the body mass index (BMI) (12). One possible explanation of the reduced APN levels in obesity may be caused by the enhanced production of proinflammatory cytokines, in particular, by TNF- $\alpha$, IL-6. Another explanation that serves to downregulate APN expression is endoplasmic reticulum (ER) stress resulting from obesity. In addition, it is demonstrated that there is a negative feedback of APN on its own production during the development of obesity (12). APN plasma concentration was found to be sex dependent, with there being a higher serum concentration in women than in men (12).

Although produced by adipose tissue, APN functions via the specific receptors, AdipoR1 and AdipoR2. Both these receptors contain seven transmembrane domains with the C-terminus inside the cells and the N-terminus outside (13). Specifically, AdipoR1, ubiquitously expressed and highly expressed in skeletal muscle, possess a high-affınity for gAPN and a low affınity for fAPN. In contrast, AdipoR2, predominantly expressed in the liver, binds both gAPN and fAPN with an intermediate affinity (13). T-cadherin has been successively discovered as a third receptor for APN, with a high affinity to HMW-APN (14). It is an atypical glycosyl phosphatidylinositol-anchored cadherin, located on the cellular surfaces of en- dothelial, epithelial, and smooth muscle cells (14). Because T-cadherin lacks both transmembrane and cytoplasmic domains, it is considered to have no effect on APN cellular signaling or function. Its main role is thought to act as an APN-binding protein, rather than a receptor.

\section{Adiponectin and prostate cancer}

Adiposity has been consistently associated with an increased risk of progression of PC, but APN is inversely related to the degree of adiposity. It seems that plasma APN should be reduced in PC patients. Goktas et al. (15) was the first to report that serum APN levels were significantly lower in patients with $\mathrm{PC}$ than in the $\mathrm{BPH}$ group or in healthy controls. In addition, APN levels were negatively associated with histological grade and disease stage. Next, a study of 300 Greek men by Michalakis et al. (16) revealed a significantly reduced risk of PC with higher plasma APN concentrations. In line with this, APN receptor levels are likewise lower in resected PC tissues. Several studies have supported the inverse association between APN and risk of PC or high-grade PC (17-21). Therefore, these findings indicated the potential role of APN in the suppression of carcinogenesis. However, as HMW-APN is the most active form of APN, Medina EA et al. (22) evaluated the relation between HMW-APN and PC, and found that only HMW-APN decreased the risk of PC in obese man. In 2006, Baillargeon et al. (23) found no correlation between APN levels and the development of PC. Furthermore, they found no association of PC with BMI, leptin and IL-6. In 2014, a study by Stevens et al. (24) also revealed APN is not associated with risk of aggressive PC. Thus, the precise role of APN in the development of PC remains elusive. In 2015, using a cross-sectional study, Ikeda A et al. (25) detected PC by prostate-specific antigen (PSA)-based screening and firstly demonstrated a significant and positive correlation between APN levels and PSA levels. One explanation was the proportion of obese men in the study was extremely low, another one was maybe the increased APN being a protective response against tumor progression, and the third one was they did not evaluate HMW-APN in this study. Finally, Liao Q (26) performed a meta-analysis of numerous stu- 
dies and concluded that patients with PC markedly had lower APN levels than controls, they also found that decreased concentration of APN was associated with a significantly greater risk of PC.

Given that APN encoding gene (ADIPOQ) and its receptor (ADIPOR) are highly polymorphic and carry several single nucleotide polymorphisms (SNPs), the genetic variants of ADIPOQ and ADIPOR might affect PC risk. In a study with 1,286 cases and 1,267 controls, Dhillon P et al. (27) found four SNPs of ADIPOQ were significantly associated with PC risk, two of which were also associated with plasma APN concentration. Furthermore, Kaklamain et al. (28) conducted a study that also noted the effects of genetic variations in ADIPOQ and ADIPOR1 gene on PC. Conversely, two other studies demonstrated no associations in candidate SNPs and PC risk (29, 30 ). Since these results were inconsistent and insufficient, an updated meta-analysis performed by $\mathrm{Hu}$ et al. revealed that ADIPOQ rs 2241766 and ADIPOR1 rs 10920531 variants were identified to be correlated with increased risk of PC. On the contrary, ADIPOR1 rs 2232853 variants were associated with decreased risk of PC (31). The identified polymorphisms might help prediction of prevalence and prognosis of PC, as well as generation of novel targeted therapies.

The relationship between APN receptors and PC has also been examined by many investigators. Mistry T et al. (32) firstly showed AdipoR1 and AdipoR2 expressed both in benign and adenocarcinomatous prostate tissue by immunohistochemistry analysis. The presence of the receptors expression suggested that APN binding to its receptors may mediate prostate physiology and pathologic changes. In 2007, Michalakis K et al. (16) showed that malignant prostate tissue samples reduced expression of APN receptors compared with benign prostate tissue. In line with APN receptors, the serum APN concentrations in patients with PC were lower than those in controls, which led to the hypothesis that receptor downregulation in PC would promote cancer progression. However, another study conducted by Rider JR et al. (33) revealed that there was a positive relationship between AdipoR2 and PC development. The relationship between APN receptors expression and carcinogenesis is somewhat controversial, therefore more studies are needed to elucidate the link between APN receptors and PC. The results of epidemiological studies of the association between APN levels and PC are summarized in Table- 1.

Potential mechanisms of adiponectin in prostate cancer

Recent advances suggested that APN plays a role in carcinogenesis through numerous mechanisms including inhibiting proliferation and inducing apoptosis (19, 20, 34-42). Recent studies have shown that activation of the adenosine monophosphate-activated protein kinase (AMPK) is a key part of the signaling cascade downstream of APN receptor $(20,34-36)$. The proteins downstream of AMPK included tuberous sclerosis protein 2 (TSC2), the mammalian homologue of the target of rapamycin (mTOR), vascular endothelial growth factor A (VEGF-A) and fatty acid synthase (FAS), all of which are involved in the regulation of cell proliferation. In PC-3 cells, activation of AMPK by APN is associated with reduction in MTOR activation, which reduces protein translation and inhibits cell growth (34). In this study, when siRNA reduced AMPK level, APN-induced growth is significantly inhibited.

Another study of modification of APN levels in PC-3 cells supported that APN activates AMPK / TSC2 to inhibit mTOR-mediated VEGF-A activation and to inhibit cancer neovascularization $(20,35)$. In addition, AMPK prevents fatty acid synthesis by downregulation FAS, then inhibited cell growth and induced apoptosis in LNCaP cancer cells (36).

Signal transducers and activator of transcription 3 (STAT3) appears to be a key regulator for cell proliferation and apoptosis. Both fAPN and gAPN can stimulate JNK activation, then drastically suppress STAT3 activation in DU145 cells, suggesting that JNK and STAT3 may constitute a universal signaling pathway to mediate APN's pathophysiological effects on PC (37).

APN also has anti-proliferation effects on many cell lines including PC3, DU145 and LNCaP PC cells $(38,39)$. APN induced cell cycle arrest of prostatic epithelial and stromal cell lines through 
Table 1 - Recent Studies showing the association between APN concentrations and risk of PC.

\begin{tabular}{|c|c|c|c|c|c|}
\hline Reference & $\begin{array}{l}\text { Sample } \\
\text { numbers }\end{array}$ & APN levels / OR & Comments / Conclusion & Other findings & TS \\
\hline \multirow[t]{3}{*}{ Goktas S (15) } & $30 \mathrm{PC}$ & $5.3 \pm 1.6 \mu \mathrm{g} / \mathrm{mL}$ & \multirow{3}{*}{$\begin{array}{l}\text { APN concentrations are } \\
\text { lower in PC than BPH or } \\
\text { in control subjects }\end{array}$} & \multirow{3}{*}{$\begin{array}{l}\text { APN are negatively } \\
\text { associated with the } \\
\text { histologic grade and } \\
\text { disease stage of PC }\end{array}$} & \multirow[t]{3}{*}{$\mathrm{CC}$} \\
\hline & $41 \mathrm{BPH}$ & $14.5 \pm 4.4 \mu \mathrm{g} / \mathrm{mL}$ & & & \\
\hline & 36 Con & $16.2 \pm 4.1 \mu \mathrm{g} / \mathrm{mL}$ & & & \\
\hline \multirow[t]{3}{*}{ Michalakis K (16) } & $75 \mathrm{PC}$ & $7.4 \pm 5.0 \mu \mathrm{g} / \mathrm{mL}$ & \multirow{3}{*}{$\begin{array}{c}\text { Higher plasma APN } \\
\text { concentrations are } \\
\text { associated with a } \\
\text { reduced risk of PC }\end{array}$} & \multirow{3}{*}{$\begin{array}{l}\text { AdipoR1 and AdipoR2 } \\
\text { in cancerous were } \\
\text { weaker expressed } \\
\text { compared with healthy } \\
\text { prostate tissue }\end{array}$} & \multirow[t]{3}{*}{$\mathrm{CC}$} \\
\hline & $75 \mathrm{BPH}$ & $11.5 \pm 6.4 \mu \mathrm{g} / \mathrm{mL}$ & & & \\
\hline & 150 Con & $12.8 \pm 8.0 \mu \mathrm{g} / \mathrm{mL}$ & & & \\
\hline \multirow[t]{2}{*}{ Schenk JM. (17) } & $698 \mathrm{BPH}$ & \multirow[t]{2}{*}{$O R=0.43$} & \multirow{2}{*}{$\begin{array}{l}\text { High APN concentrations } \\
\text { were associated with } \\
\text { reduced risk of BPH }\end{array}$} & \multirow{2}{*}{$\begin{array}{l}\text { Neither C-peptide nor } \\
\text { leptin was associated } \\
\text { with BPH risk }\end{array}$} & \multirow[t]{2}{*}{ NCC } \\
\hline & 709 Con & & & & \\
\hline \multirow[t]{3}{*}{ Li H (18) } & 654 PC & Q1: $2.7 \mu \mathrm{g} / \mathrm{mL}$ & \multirow{3}{*}{$\begin{array}{c}\text { Higher APN } \\
\text { concentrations have a } \\
\text { lower risk for developing } \\
\text { high-grade or metastatic } \\
\text { cancer }\end{array}$} & \multirow{3}{*}{$\begin{array}{l}\text { Leptin was unrelated to } \\
\text { PC risk or mortality }\end{array}$} & \multirow[t]{3}{*}{$\mathrm{NCC}$} \\
\hline & 644 Con & Q3: $6.3 \mu \mathrm{g} / \mathrm{mL}$ & & & \\
\hline & & Q5: $13.3 \mu \mathrm{g} / \mathrm{mL}$ & & & \\
\hline \multirow[t]{4}{*}{ Tan W (19) } & $96 \mathrm{PC}$ & Low level of APN & \multirow{3}{*}{$\begin{array}{l}\text { APN was significantly } \\
\text { decreased in PC } \\
\text { compared with that of } \\
\text { BPH tissues }\end{array}$} & \multirow{4}{*}{$\begin{array}{l}\text { APN may function as } \\
\text { a tumor suppressor } \\
\text { through inhibiting EMT } \\
\text { of PC cells. }\end{array}$} & \multirow[t]{4}{*}{$\mathrm{CC}$} \\
\hline & $15 \mathrm{BPH}$ & $\begin{array}{c}\text { BPH: } 1 \text { of } 15(6.7 \%) \text { GS } \\
<7: 6 \text { of } 27(22 \%)\end{array}$ & & & \\
\hline & & $\mathrm{GS}=7: 18$ of $26(69 \%)$ & & & \\
\hline & & GS > 7: $320 f 43(74 \%)$ & $\begin{array}{l}\text { Decreased APN level } \\
\text { was significantly } \\
\text { associated with high GS }\end{array}$ & & \\
\hline \multirow[t]{2}{*}{ Medina EA (22) } & $228 \mathrm{PC}$ & $\mathrm{OR}=0.62$ & \multirow{2}{*}{$\begin{array}{c}\text { Only HMW APN } \\
\text { decreased the risk of PC } \\
\text { in obese man }\end{array}$} & \multirow{2}{*}{$\begin{array}{l}\text { HMW increased the risk } \\
\text { of PC in normal and } \\
\text { overweight men }\end{array}$} & \multirow[t]{2}{*}{ NCC } \\
\hline & 239 Con & & & & \\
\hline \multirow[t]{2}{*}{ Baillargeon J (23) } & $125 \mathrm{PC}$ & $17.9 \pm 0.6 \mu \mathrm{g} / \mathrm{mL}$ & \multirow{2}{*}{$\begin{array}{l}\text { APN was not significant } \\
\text { associated with PC risk }\end{array}$} & \multirow{2}{*}{$\begin{array}{c}\text { BMI was not associated } \\
\text { with incident PC }\end{array}$} & \multirow[t]{2}{*}{ NCC } \\
\hline & 125 Con & $19.9 \pm 13.2 \mu \mathrm{g} / \mathrm{mL}$ & & & \\
\hline \multirow[t]{2}{*}{ Stevens VL. (24) } & $272 \mathrm{PC}$ & $\mathrm{OR}=1.11$ & \multirow{2}{*}{$\begin{array}{c}\text { APN was not associated } \\
\text { with risk of aggressive } \\
\text { PC }\end{array}$} & \multirow{2}{*}{$\begin{array}{c}\text { C-peptide was not } \\
\text { associated with risk } \\
\text { of aggressive prostate } \\
\text { cancer }\end{array}$} & \multirow[t]{2}{*}{$\mathrm{NCC}$} \\
\hline & 272 Con & & & & \\
\hline \multirow[t]{2}{*}{ Ikeda A. (25) } & $24 P C$ & $9.96 \mu \mathrm{g} / \mathrm{mL}$ & APN was significantly & High APN increased & CS \\
\hline & 2817 Con & $7.64 \mu \mathrm{g} / \mathrm{mL}$ & $\begin{array}{l}\text { and positively associated } \\
\text { with PSA levels }\end{array}$ & $\begin{array}{c}\text { the Incidence of low- } \\
\text { or mediate-risk PC in } \\
\text { obese man }\end{array}$ & \\
\hline
\end{tabular}

$\mathbf{A P N}=$ adiponectin; $\mathbf{P C}=$ prostate cancer; $\mathbf{B P H}=$ benign prostatic hyperplasia; Con = Control; $\mathbf{T S}$ = type of study; $\mathbf{C C}=$ case - control; $\mathbf{N C C}=$ nested-case-control; $\mathbf{C S}=$ cross-sectional; $\mathbf{O R}$ = odds ratio; $\mathbf{Q 5}$ = Highest quintile; $\mathbf{Q 3}$ = intermediate Quintile; $\mathbf{Q 1}$ = Lowest Quintile; $\mathbf{G S}=$ Gleason score; $\mathbf{P S A}=$ prostate-specific antigen. 
the downregulation of cyclinD1 and PCNA, which attenuated the growth factor-mediated proliferation. Additionally, APN induced apoptosis by increasing caspase 3, Bax expression and downregulation of $\mathrm{Bcl} 2$ (40).

Furthermore, APN significantly inhibits cell proliferation induced by leptin. Different leptin / adiponectin ratios resulted in varying inhibitory effects on PC cells, indicating the balance between APN and leptin might effectively modulate PC cell growth. APN can attenuate the adverse effects of leptin and inhibit LNCaP and PC3 proliferation via modulation of $\mathrm{p} 53$ and bcl-2 expression (41), hence the balance of leptin and APN may be important in driving obesity-related PC progression.

Oxidative stress (OS) is a key event in the initiation, development and progression of PC. APN increased cellular anti-oxidative defense mechanisms and inhibited OS via increasing NADPH oxidase NOX2 and NOX4 expression in human 22Rv1 and DU-145 PC cell lines (42). Despite an increasing accumulation of experimental data, the mechanisms underlying the anti-proliferative and tumor-suppressing effects of APN are still not fully understood, more studies are needed. The role of APN in PC is summarized in Figure-1.

\section{Clinical values of Adiponectin for prostate cancer patients}

Based on the signaling pathway conducted by APN and its receptors, APN might represent a promising therapeutic target. Currently, the administration of APN or direct antagonist has not been reported in the literature for the treatment of human cancers. A strategy for the future treatment of PC patients with hypoadiponectinemia may include the upregulation of APN levels, APN receptors, or the development of APN receptor agonists.

Tangible benefits may come from the anti-diabetic drug Metformin. Metformin partially mimicked APN action and activate AMPK signaling in PC-3 cells, with reduction of mTOR activity thus inhibition of cell growth, suggesting that Metformin might have particular va- lue in attenuating the adverse effects of hypoadiponectinemia on PC (34). Metformin therapy has been correlated with reduced risk of prostate cancer in Caucasian / white men with diabetes (43) and with a survival benefit after diagnosis (44). These results underscore the importance for further studies to evaluate metformin in PC. Plasma APN levels can also be upregulated by thiazolidinediones (TZDs), such as pioglitazone, rosiglitazone, a class of PPAR $-\gamma$ agonists and medicine used in the treatment of type II diabetes (T2D). Clinically, Metformin and thiazolidinedione therapy improved survival of diabetics prostate cancer patients (45).

Down-regulation of APN in PC tissues and LNCaP cells owing to highly methylation in its promoter, and 5-AZA restored its expression in vitro. Thus, methylation of APN promoter may be a key factor for evaluation of PC, and 5-AZA may be a promising stimulator of APN (19). Zorn CS et al. (46) reported that 5-AZA improves survival in the transgenic adenocarcinoma of the mouse prostate (TRAMP) model.

Previous research suggested that diet pattern as well as physical activity might increase expression of APN and delay disease progression in PC patients $(47,48)$. Hence, moderate physical exercise, reduction of body fat, associated with restriction of calories in diet are recommended for obesity-related prostate cancer prevention.

Another potential therapeutic molecule is the APN receptor agonist. Agonists have been developed and tested to treat multiple diseases related to hypoadiponectinemia, diabetes and other malignancies $(49,50)$. ADP355, a first-in-class APN receptor agonist, restricted proliferation in several APN receptor-positive cancer cell lines, and suppressed the growth of established tumors by 31\% in vivo (49). AdipoRon, with similar effects to APN, increased apoptosis while inhibiting pancreatic cell proliferation and colony formation. In vivo, treatment of mice with AdipoRon inhibits orthotopic pancreatic tumor growth (50). APN receptor agonists may represent novel therapeutic strategies for PC in future. 
Figure-1 - Signaling pathways of adiponectin in prostate cancer cells.

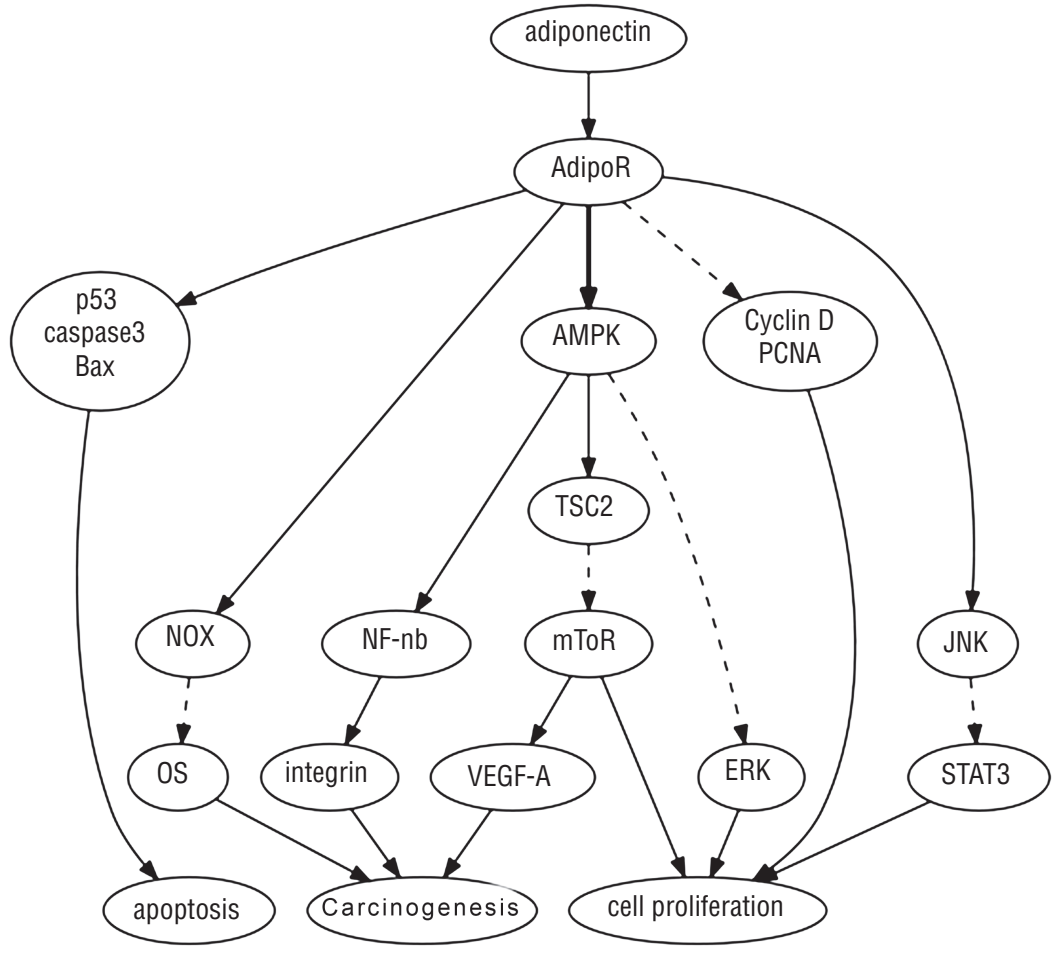

JNK = c-Jun N-terminal kinase; $\mathbf{S T A T 3}$ = signal transducer and activator of transcription; $\mathbf{A M P K}=$ AMP-activated protein kinase; $\mathbf{T S C 2}$ = tuberous sclerosis complex 2 ; $\mathbf{m T O R}=$ mammalian target of rapamycin; $\mathbf{N F - K B}=$ nuclear factor-KB; NOX = NADPH oxidase; $\mathbf{O S}=$ oxidative stress; $\downarrow$ indicates stimulation; $\downarrow$ indicates inhibition.

\section{CONCLUSIONS}

Numerous studies supporting the notion that APN acts as a protective and safe factor to prevent progression of PC, but few studies may indicate otherwise. We summarized the mechanisms underlying the anti-proliferative and tumor-suppressing effects of APN specifically in PC without reiterating other types of cancers. The signaling pathways linking APN with tumorigenesis involve several key molecules, including AdipoRs, AMPK, JNK, NOX, NF- $\kappa \mathrm{B}$, and so on, thus providing potential drug targets for the future. Based on the beneficial effects induced by APN, future efforts can focus on increasing APN and its receptors levels in response to PC. Since APN exerts pleiotropic effects on different tissues and exists as a high serum concentration protein, the main role of APN should be regulation of metabolism, not necessarily to act as an anti-cancer hormone. We must consi- der many other risk factors for PC with a lower level of APN, which could help develop better approaches for the treatment and prevention of all men with PC. Moreover, further research is warranted to better understand the pathophysiological role of APN in obesity and obesity-related PC, and elucidate the potential clinical application in humans.

\section{ACKNOWLEDGEMENTS}

This work was supported by Nature Science Fund of Hunan Province (2016JJ2113), Science Fund of Hunan Provincial Education Department (16A186), Hengyang Science and Technology Board (2015KJ15), the University of South China (2014XQD40, 2017JG022).

\section{CONFLICT OF INTEREST}

None declared. 


\section{REFERENCES}

1. Pernar CH, Ebot EM, Wilson KM, Mucci LA. The Epidemiology of Prostate Cancer. Cold Spring Harb Perspect Med. 2018. [Epub ahead of print]

2. Siegel RL, Miller KD, Jemal A. Cancer statistics, 2018. CA Cancer J Clin. 2018;68:7-30.

3. Abdulhussein D, Amin E. Translation of the link between cancer and obesity to patients. Lancet. 2018;391:121-2.

4. Bultman SJ. A Reversible Epigenetic Link between Obesity and Cancer Risk. Trends Endocrinol Metab. 2018;29:52931.

5. Roberts DL, Dive C, Renehan AG. Biological mechanisms linking obesity and cancer risk: new perspectives. Annu Rev Med. 2010;61:301-16.

6. Smith LA, O'Flanagan CH, Bowers LW, Allott EH, Hursting SD. Translating Mechanism-Based Strategies to Break the Obesity-Cancer Link: A Narrative Review. J Acad Nutr Diet. 2018;118:652-67.

7. Gairolla J, Kler R, Modi M, Khurana D. Leptin and adiponectin: pathophysiological role and possible therapeutic target of inflammation in ischemic stroke. Rev Neurosci. 2017;28:295306.

8. Frankenberg ADV, Reis AF, Gerchman F. Relationships between adiponectin levels, the metabolic syndrome, and type 2 diabetes: a literature review. Arch Endocrinol Metab. 2017;61:614-22.

9. Barb D, Pazaitou-Panayiotou K, Mantzoros CS. Adiponectin: a link between obesity and cancer. Expert Opin Investig Drugs. 2006;15:917-31.

10. van Andel $M$, Heijboer $A C$, Drent ML. Adiponectin and Its Isoforms in Pathophysiology. Adv Clin Chem. 2018;85:115-47.

11. Fruebis J, Tsao TS, Javorschi S, Ebbets-Reed D, Erickson $\mathrm{MR}$, Yen FT, et al. Proteolytic cleavage product of $30-\mathrm{kDa}$ adipocyte complement-related protein increases fatty acid oxidation in muscle and causes weight loss in mice. Proc Natl Acad Sci U S A. 2001;98:2005-10.

12. Dalamaga M, Diakopoulos KN, Mantzoros CS. The role of adiponectin in cancer: a review of current evidence. Endocr Rev. 2012;33:547-94.

13. Yamauchi $T$, Iwabu M, Okada-Iwabu M, Kadowaki $T$. Adiponectin receptors: a review of their structure, function and how they work. Best Pract Res Clin Endocrinol Metab. 2014;28:15-23.
14. Fukuda S, Kita S, Obata Y, Fujishima Y, Nagao H, Masuda $S$, et al. The unique prodomain of T-cadherin plays a key role in adiponectin binding with the essential extracellular cadherin repeats 1 and 2. J Biol Chem. 2017;292:7840-9.

15. Goktas S, Yilmaz MI, Caglar K, Sonmez A, Kilic S, Bedir S. Prostate cancer and adiponectin. Urology. 2005;65:1168-72.

16. Michalakis K, Williams CJ, Mitsiades N, Blakeman J, Balafouta-Tselenis S,Giannopoulos A, et al. Serum adiponectin concentrations and tissue expression of adiponectin receptors are reduced in patients with prostate cancer: a case control study. Cancer Epidemiol Biomarkers Prev. 2007;16:308-13.

17. Schenk JM, Kristal AR, Neuhouser ML, Tangen CM, White E, Lin DW, Thompson IM. Serum adiponectin, C-peptide and leptin and risk of symptomatic benign prostatic hyperplasia: results from the Prostate Cancer Prevention Trial. Prostate. 2009;69:1303-11

18. Li H, Stampfer MJ, Mucci L, Rifai N, Qiu W, Kurth T, et al. A 25-year prospective study of plasma adiponectin and leptin concentrations and prostate cancer risk and survival. Clin Chem. 2010;56:34-43.

19. Tan W, Wang L, Ma Q, Qi M, Lu N, Zhang L, et al. Adiponectin as a potential tumor suppressor inhibiting epithelial-tomesenchymal transition but frequently silenced in prostate cancer by promoter methylation. Prostate. 2015;75:1197-205.

20. Gao Q, Zheng J, Yao X, Peng B. Adiponectin inhibits VEGF-A in prostate cancer cells. Tumour Biol. 2015;36:4287-92.

21. Burton A, Martin RM, Holly J, Lane JA, Donovan JL, Hamdy FC, et al. Associations of adiponectin and leptin with stage and grade of PSA-detected prostate cancer: the ProtecT study. Cancer Causes Control. 2013;24:323-34.

22. Medina EA, Shi X, Grayson MH, Ankerst DP, Livi CB, Medina MV, et al. The diagnostic value of adiponectin multimers in healthy men undergoing screening for prostate cancer. Cancer Epidemiol Biomarkers Prev. 2014;23:309-15.

23. Baillargeon J, Platz EA, Rose DP, Pollock BH, Ankerst DP, Haffner S, et al. Obesity, adipokines, and prostate cancer in a prospective population-based study. Cancer Epidemiol Biomarkers Prev. 2006;15:1331-5.

24. Stevens VL, Jacobs EJ, Sun J, Gapstur SM. No association of plasma levels of adiponectin and c-peptide with risk of aggressive prostate cancer in the Cancer Prevention Study II Nutrition Cohort. Cancer Epidemiol Biomarkers Prev. 2014:23:890-2. 
25. Ikeda A, Nakagawa T, Kawai K, Onozawa M, Hayashi T, Matsushita $Y$, et al. Serum adiponectin concentration in 2,939 Japanese men undergoing screening for prostate cancer. Prostate Int. 2015;3:87-92.

26. Liao $Q$, Long $\mathrm{C}$, Deng Z, Bi X, Hu J. The role of circulating adiponectin in prostate cancer: a meta-analysis. Int $\mathrm{J}$ Biol Markers. 2015;30:e22-31.

27. Dhillon PK, Penney KL, Schumacher F, Rider JR, Sesso HD, Pollak M, et al. Common polymorphisms in the adiponectin and its receptor genes, adiponectin levels and the risk of prostate cancer. Cancer Epidemiol Biomarkers Prev. 2011;20:2618-27.

28. Kaklamani V, Yi N, Zhang K, Sadim M, Offit K, Oddoux C, et al. Polymorphisms of ADIPOQ and ADIPOR1 and prostate cancer risk. Metabolism. 2011;60:1234-43.

29. Moore SC, Leitzmann MF, Albanes D, Weinstein SJ, Snyder $\mathrm{K}$, Virtamo J, et al. Adipokine genes and prostate cancer risk. Int J Cancer. 2009;124:869-76.

30. Beebe-Dimmer JL, Zuhlke KA, Ray AM, Lange EM, Cooney KA. Genetic variation in adiponectin (ADIPOQ) and the type 1 receptor (ADIPOR1), obesity and prostate cancer in African Americans. Prostate Cancer Prostatic Dis. 2010;13:362-8.

31. Hu MB, Xu H, Hu JM, Zhu WH, Yang T, Jiang HW, et al. Genetic polymorphisms in leptin, adiponectin and their receptors affect risk and aggressiveness of prostate cancer: evidence from a meta-analysis and pooled-review. Oncotarget. 2016;7:81049-61.

32. Mistry T, Digby JE, Chen J, Desai KM, Randeva HS. The regulation of adiponectin receptors in human prostate cancer cell lines. Biochem Biophys Res Commun. 2006;348:832-8.

33. Rider JR, Fiorentino M, Kelly R, Gerke T, Jordahl K, Sinnott $\mathrm{JA}$, et al. Tumor expression of adiponectin receptor 2 and lethal prostate cancer. Carcinogenesis. 2015;36:639-47.

34. Zakikhani M, Dowling RJ, Sonenberg N, Pollak MN. The effects of adiponectin and metformin on prostate and colon neoplasia involve activation of AMP-activated protein kinase. Cancer Prev Res (Phila). 2008;1:369-75. Erratum in: Cancer Prev Res (Phila Pa). 2009;2:95.

35. Gao Q, Yao X, Zheng J. MiR-323 Inhibits Prostate Cancer Vascularization Through Adiponectin Receptor. Cell Physiol Biochem. 2015;36:1491-8.

36. Brusselmans K, De Schrijver E, Verhoeven G, Swinnen JV. RNA interference-mediated silencing of the acetylCoA-carboxylase-alpha gene induces growth inhibition and apoptosis of prostate cancer cells. Cancer Res. 2005;65:6719-25.
37. Miyazaki T, Bub JD, Uzuki M, Iwamoto Y. Adiponectin activates c-Jun NH2-terminal kinase and inhibits signal transducer and activator of transcription 3. Biochem Biophys Res Commun. 2005;333:79-87.

38. Gao Q, Zheng J. Adiponectin-induced antitumor activity on prostatic cancers through inhibiting proliferation. Cell Biochem Biophys. 2014;70:461-5.

39. Bub JD, Miyazaki T, Iwamoto Y. Adiponectin as a growth inhibitor in prostate cancer cells. Biochem Biophys Res Commun. 2006;340:1158-66.

40. Fu S, Xu H, Gu M, Liu C, Wang Q, Wan X, et al. Adiponectin deficiency contributes to the development and progression of benign prostatic hyperplasia in obesity. Sci Rep. 2017;7:43771.

41. Mistry T, Digby JE, Desai KM, Randeva HS. Leptin and adiponectin interact in the regulation of prostate cancer cell growth via modulation of p53 and bcl-2 expression. BJU Int. 2008;101:1317-22.

42. Lu JP, Hou ZF, Duivenvoorden WC, Whelan K, Honig A, Pinthus $\mathrm{JH}$. Adiponectin inhibits oxidative stress in human prostate carcinoma cells. Prostate Cancer Prostatic Dis. 2012;15:28-35.

43. Wright JL, Stanford JL. Metformin use and prostate cancer in Caucasian men: results from a population-based casecontrol study. Cancer Causes Control. 2009;20:1617-22.

44. Xiao Y, Zheng L, Mei Z, Xu C, Liu C, Chu X, et al. The impact of metformin use on survival in prostate cancer: a systematic review and meta-analysis. Oncotarget. 2017;8:100449-58.

45. He XX, Tu SM, Lee MH, Yeung SC. Thiazolidinediones and metformin associated with improved survival of diabetic prostate cancer patients. Ann Oncol. 2011;22:2640-5.

46. Zorn CS, Wojno KJ, McCabe MT, Kuefer R, Gschwend JE, Day ML. 5-aza-2'-deoxycytidine delays androgenindependent disease and improves survival in the transgenic adenocarcinoma of the mouse prostate mouse model of prostate cancer. Clin Cancer Res. 2007;13:2136-43.

47. Wright JL, Plymate S, D'Oria-Cameron A, Bain C, Haugk K, Xiao L, et al. A study of caloric restriction versus standard diet in overweight men with newly diagnosed prostate cancer: a randomized controlled trial. Prostate. 2013;73:1345-51.

48. Hvid $T$, Lindegaard $B$, Winding $K$, Iversen $P$, Brasso $K$, Solomon TP, et al. Effect of a 2-year home-based endurance training intervention on physiological function and PSA doubling time in prostate cancer patients. Cancer Causes Control. 2016;27:165-74. 
49. Otvos L Jr, Haspinger E, La Russa F, Maspero F, Graziano P, Kovalszky I, et al. Design and development of a peptidebased adiponectin receptor agonist for cancer treatment. BMC Biotechnol. 2011;11:90.
50. Messaggio F, Mendonsa AM, Castellanos J, Nagathihalli NS, Gorden L, Merchant NB, et al. Adiponectin receptor agonists inhibit leptin induced PSTAT3 and in vivo pancreatic tumor growth. Oncotarget. 2017;8:85378-91.

Correspondence address:

Zhaohui Cao, PhD

Hunan Province Cooperative

Innovation Center for Molecular

Target New Drug Study, University of South China

Hengyang, China

Telephone: + 860734 828-1372

E-mail:caozhaohui72@sina.com 